\title{
Primary bandages for people with pemphigus vulgaris lesions: an integrative literature review
}

\author{
Coberturas primárias em pessoas com lesões por pênfigo \\ vulgar: revisão integrativa de literatura \\ Coberturas primarias en personas con lesiones por pénfigo \\ vulgar: revisión integradora de literatura
}

\section{Hayana Pereira Leal Soares ${ }^{\mathrm{a}}$ Euzeli da Silva Brandão ${ }^{b}$ Renato Tonolec}

\section{How to cite this article:} Soares HPL, Brandão ES, Tonole R. Primary bandages for people with pemphigus vulgaris lesions: an integrative literature review. Rev Gaúcha Enferm. 2020;41:e20190259. doi: https://doi. org/10.1590/1983-1447.2020.20190259
Hospital Universitário Antônio Pedro (HUAP). Niterói, Rio de Janeiro, Brasil.

${ }^{\circ}$ Universidade Federal Fluminense (UFF), Escola de Enfermagem Aurora de Afonso Costa, Departamento de Fundamentos de Enfermagem e Administração. Niterói, Rio de Janeiro, Brasil.

Instituto Nacional de Câncer José Alencar Gomes da Silva (INCA), Hospital do Câncer I. Rio de Janeiro, Rio de Janeiro, Brasil.

\section{ABSTRACT}

Objective: To identify the primary bandages recommended in the literature to dress the wounds of people with pemphigus vulgaris and to describe the positive or negative repercussions related to these bandages.

Method: Integrative literature review, using the descriptors "dressing", "nursing care", "nursing", "skin diseases / vesiculobollous" and "pemphigus"; inclusion criteria: articles that address primary bandages for pemphigus vulgaris skin lesion dressing; published between 2010 and 2017; in Portuquese, English or Spanish; indexed in BDENF, LILACS, PubMed, and/or Scopus.

Results: eight articles were selected, seven had evidence levels 4 and 5 and one had evidence level 3. The primary bandages covered were: silver gel, hydrocolloid, hydrogel, silver-containing hydrofiber, antibiotics, sterilized vaseline, corticoid, and vitamin E ointment Conclusion: Sterile gauze with vaseline, prepared according to protocol, was the bandage presented in the study with the most significant level of evidence.

Keywords: Nursing. Nursing care. Dermatology. Pemphigus. Bandages.

\section{RESUMO}

Objetivo: Identificar a(s) cobertura(s) primária(s) preconizada(s) na literatura para a realização do curativo da pessoa com pênfigo vulgar; descrever as repercussões favoráveis ou desfavoráveis relacionadas a essas coberturas.

Método: Revisão integrativa de literatura, utilizando os descritores"bandages","nursing care","nursing","skin diseases/vesiculobollous" e"pemphigus"; critérios de inclusão: abordar a cobertura primária para o curativo de pessoas com lesões cutâneas por pênfigo vulgar; publicados entre 2010 e 2017; em português, inglês ou espanhol; indexados na BDENF, LLLACS, PubMed e Scopus.

Resultados: Selecionou-se 08 artigos, sendo sete artigos com níveis de evidência 4 e 5 e apenas um artigo com nível de evidência 3. As coberturas primárias abordadas foram: gel de prata, hidrocolóide, hidrogel, hidrofibra com prata, antibióticos, vaselina esterilizada, pomada à base de corticóide e vitamina $\mathrm{E}$.

Conclusão: A gaze vaselinada estéril, preparada conforme protocolo, foi a cobertura apresentada em estudo com nível de evidência mais significativo.

Palavras chave: Enfermagem. Cuidados de enfermagem. Dermatologia. Pênfigo. Bandagens.

\section{RESUMEN}

Objetivo: Identificar las coberturas principales recomendadas en la literatura para vestir a la persona con pénfigo vulgar; describa las repercusiones favorables o desfavorables relacionadas con esta cobertura.

Método: Revisión integral de la literatura, utilizando los descriptores" vendajes", "atención de enfermería","enfermería","enfermedades cutáneas / vesiculoampolhosas"y"pénfigo"; criterios de inclusión: abordar la cobertura de vendaje primario de personas con lesiones cutáneas por pénfigo vulgar; publicado entre 2010 y 2017; publicado en portugués, inglés o español; indexado en BDENF, LILACS, PubMed y Scopus.

Resultados: Seleccionamos 08 artículos, siete artículos con niveles de evidencia 4 y 5 y solo un artículo con nivel de evidencia 3. La cobertura principal abordada fue: gel de plata, hidrocoloide, hidrogel, hidrofibra con plata, antibióticos, vaselina esterilizada, pomada de corticoides y vitamina $\mathrm{E}$.

Conclusión: La gasa vaselinada estéril, preparada según el protocolo, fue la portada presentada en un estudio con el nivel de evidencia más significativo.

Palabras clave: Enfermería. Atención de enfermería. Dermatología. Pénfigo.Vendajes. 


\section{口INTRODUCTION}

Pemphigus is a blistering autoimmune dermatosis, tending to progression, chronic and unlimited evolution, and has a reserved prognosis ${ }^{(1)}$. In Brazil, researches have shown a greater incidence of pemphigus vulgaris (PV) when compared to the other clinical variants of pemphigus ${ }^{(2)}$. This pathology is relatively rare and mostly affects white people above 40 years of age, regardless of sex. Generally, the disease starts with blisters in the oral mucosa that can last for months before cutaneous manifestations ${ }^{(1)}$.

The skin of a person diagnosed with PV goes through acantholysis, meaning that an intra-epidermal degeneration takes place and generates inter-cellular fissures that are then filled with liquids, resulting in the formation of ephemeral and superficial blisters. After these blisters break, erosive and exuding areas are revealed, which can cause pruritus and "burning"(2), in addition to pain and a foul smell similar to the "rat nests"(1). These lesions have varying sizes and can be isolated, but tend to become general, becoming large and disseminated. Another important feature of this disease is the Nikolsky sign, which indicates the activity of the disease and is marked by friction or pressure in the seemingly normal skin around the lesion and leading to epidermal displacement (positive)(1).

Desmosomes are known to be changes in the cellular surface responsible for the adherence between keratinocytes throughout the epidermis. According to the type of pemphigus, certain glycoproteins that make up desmosomes become antigenic and induce the production of autoantibodies. Currently, the etiology of this phenomenon is considered to be idiopathic(1).

In PV, the location of the acantholytic rifts is immediately above the deepest epidermal layer, that is, the basal layer, meaning the prognosis for this variant is less optimistic than that of others, in which acantholysis takes place in more superficial layers.

Medication treatment includes high doses of corticoids. In non-responsive forms of the disease, the administration of methylprednisolone is common, sometimes associated with immunosuppressors. In general, the death of people with this disease results from infections and/or complications secondary to the therapies used ${ }^{(1)}$.

Considering the specificity and complexity of these lesions, some medical teams are against the use of wound dressing for these clients, although this conduct does not minimize the risk of new blisters, adherence, pain, discomfort, infections, and infestations ${ }^{(2)}$.

In this context, the choice of a dressing that can guarantee a safe environment for healing must be in accordance to the following criteria: be easy to apply and remove; stay on the site of the lesion until the dressing is removed; manage the exudate excess; promote a humid environment; allow gaseous exchange; promote thermal isolation; aid in microbial control; prevent infestations; be comfortable, malleable, and flexible; prevent the surfacing of new lesions; aid in pain control; control the smell; not adhere to the skin around the lesion nor to the site of the lesion; be non-toxic and hypoallergenic; prevent dead space; aid in hemostasis; and offer good value for its efficiency ${ }^{(2-3)}$.

Primary bandages are "all materials, substances or products that are applied on the wound, forming a physical barrier capable of, at least, covering and protecting the site ${ }^{\prime \prime(3)}$. Considering the above, this study aims to identify the primary bandages prescribed by literature for wound dressings in people with $\mathrm{PV}$, and to describe the positive or negative repercussions associated to the use of these bandages.

\section{口 METHODOLOGY}

This is an integrative literature review (ILR), a methodological strategy that allows for a "synthesis and analysis of scientific knowledge already produced on the theme investigated"(4).

Scientific evidence is an essential element of ILRs. Said evidence is formed by the information used to confirm or deny a theory or scientific hypotheses. This is associated to evidence-based practices, which are related to the synthesis of scientific knowledge and its use for decision making in nursing clinical practice ${ }^{(5)}$.

Aiming to systematize research, six different steps must be carried out: 1 . identifying the theme and elaborating the guiding question of the research; 2 . search or sampling of literature; 3 . data collection from the selected studies; 4. critical analysis of studies included; 5 . discussion of results; 6. presentation of review/knowledge synthesis ${ }^{(6)}$.

In the first stage, the research question was elaborated using the PIO strategy, an acronym that stands for "population, intervention, and outcome". This method allows one to specifically and scientifically limit the issue or problem one wishes to investigate ${ }^{(5)}$.

Considering this, the letter $P$ was found to refer to people with $\mathrm{PV}$, the letter I to primary bandages, and the letter $\mathrm{O}$ to wound dressing, leading to the following guiding question: What is/are the primary bandage/s recommended to dress the wounds of people with PV skin lesions?

In the second stage, the following criteria were taken into account: articles that addressed the indication of primary bandages for dressing the wounds of people with PV skin lesions; that were available online; published 
from 2010 to 2017; available in Portuguese, English, or Spanish; and indexed in the following databases: Base de Dados de Enfermagem (BDENF), Literatura Latino-Americana e do Caribe em Ciências da Saúde (LILACS), National Library of Medicine (PubMed) and SciVerse (Scopus). The bibliographic survey was carried out in March 2018, using descriptors identified in the bases Descritores Ciências da Saúde (Health Science Descriptors - DeCS/Bireme) and Medical Subject Headings (MeSH/PubMed): "curativos" ("dressing"), "cuidados de enfermagem" ("nursing care"), "enfermagem" ("nursing"), "dermatopatias vesiculobolhosas" ("skin diseases/vesiculobollous"), "pênfigo" ("pemphigus"). The descriptors were combined using the boolean operator "AND". After the results from this search strategy were yielded, a triage took place via the reading of titles and abstracts. Duplicates and articles that were not in accordance to the objective/guiding question of this study were excluded (Image 1).

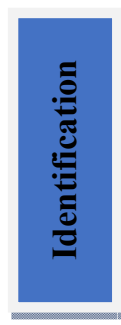

\begin{tabular}{|c|}
\hline Articles found through the research in \\
databases $(\mathrm{N}=1289)$ \\
BDENF $=6$ \\
LILACS $=569$ \\
PubMed $=646$ \\
Scopus $=68$
\end{tabular}
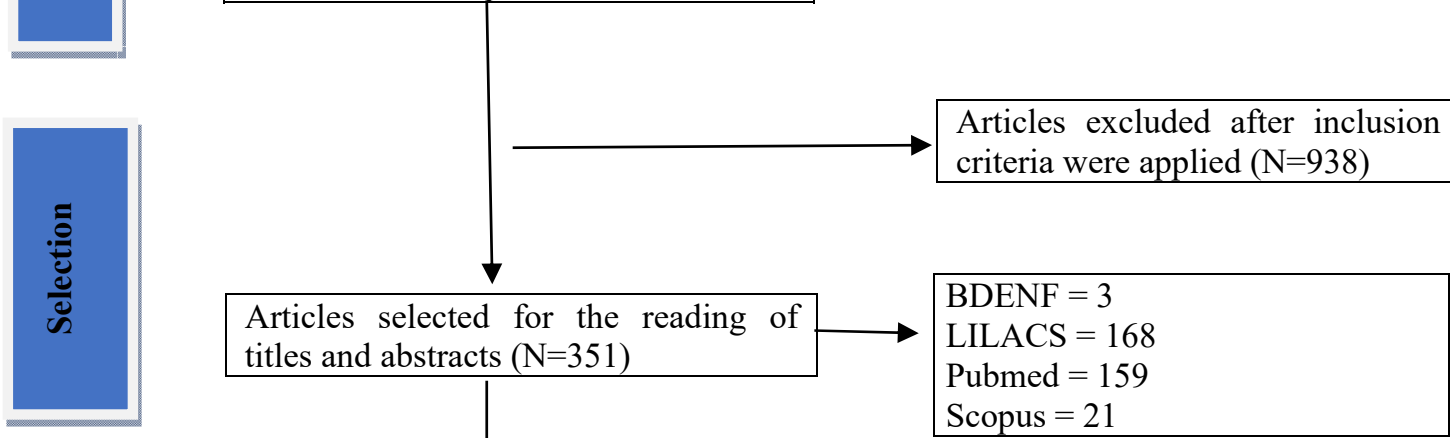

Articles excluded after inclusion criteria were applied $(\mathrm{N}=938)$

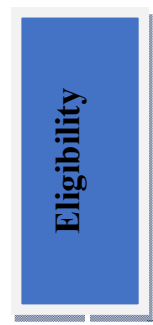

Articles selected for full reading after titles and abstracts were carefully read $(\mathrm{N}=29)$
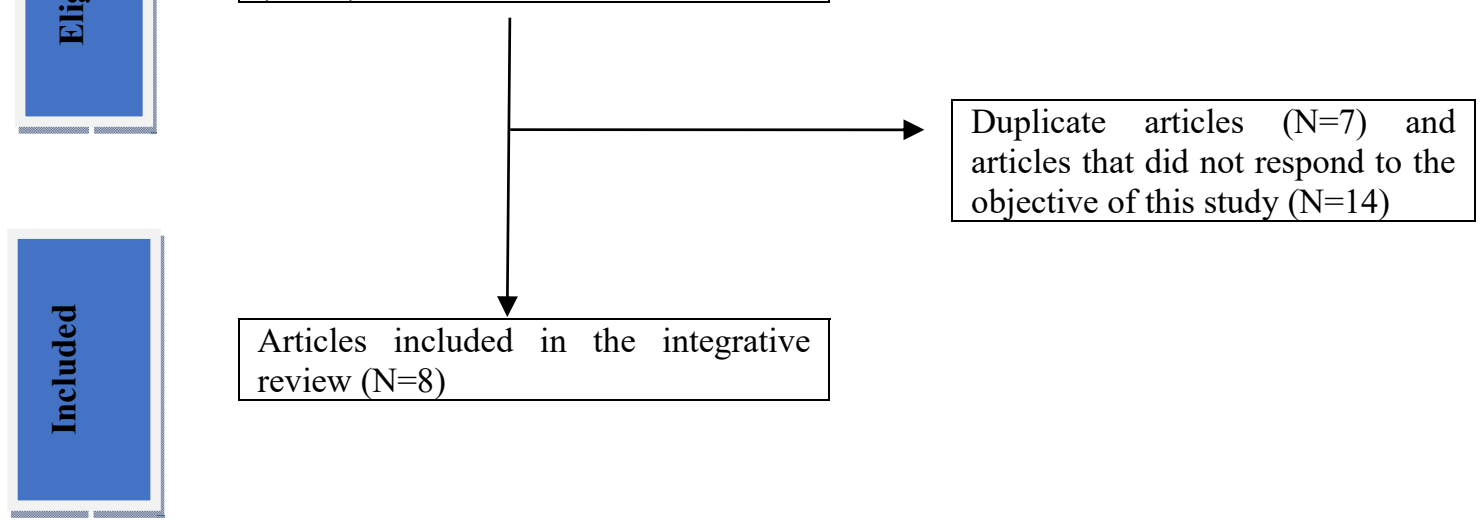

Articles included in the integrative review $(\mathrm{N}=8)$

Image 1 - Flowchart with the results of article selection

Source: The authors, 2018. 
In the third stage, data was extracted from the articles selected using an instrument that included the following variables: databases; title of the article; name of the authors; year of publication; professional category; country of origin; type of study; and evidence level. This form guarantees that all data considered relevant would be collected ${ }^{(6)}$.

In the fourth stage, the ranking system of evidence quality was used: level 1: evidences resulting from the meta-analysis of multiple randomized and controlled studies; level 2 : evidences of individual studies with experimental designs; level 3: evidences of quasi-experimental studies, temporal series, or control cases; level 4: evidences of descriptive studies (qualitative or non-experimental); level 5: evidences of case reports or experience reports; level 6: evidences based on the opinions of specialist committees, including the interpretation of information that does not originate from researches, and regulating and legal opinions $s^{(7)}$.

Regarding the fifth stage of the review, it was possible to confront the results with the theoretical referents, and, as a result, find gaps in knowledge, expose conclusions and biases of the research ${ }^{(6)}$.
Finally, in the last stage, the knowledge produced on the theme researched was synthesized.

\section{RESULTS}

Chart 1 shows the profile of the scientific publications on the bandages recommended for wound dressing in people with PV from 2010 to 2017.

Chart 1 shows an absence of articles that address the subject at hand in the PubMed database. Two articles were found repeated in three databases, BDENF, LILACS, and Scopus. In addition, three of the selected articles were written by the same Brazilian nurse, who also wrote the most recent publication (2016). Most publications are in the field of nursing. Most works were elaborated in Brazil (5), while the others originated in Mexico (1), Colombia (1), and Italy (1). Regarding the method, there were 5 case studies, 2 literature reviews, and one quasi-experimental study. The studies, respectively, had evidence levels of 5,4, and 3. References addressing the bandages of people affected by PV were found to be scarce. Chart 2 shows the synthesis of the productions selected during the search.

\begin{tabular}{|c|c|c|c|c|c|c|}
\hline $\mathbf{N}$ & Database & Title & Author & $\begin{array}{c}\text { Year } \\
\text { Category }\end{array}$ & Country & $\begin{array}{l}\text { Type of study/ } \\
\text { Level of evidence }\end{array}$ \\
\hline 1 & BDENF & $\begin{array}{l}\text { Aplicación de un plano } \\
\text { de cuidados enfermeros } \\
\text { utilizando el modelo } \\
\text { de Virginia Henderson } \\
\text { (catorce necesidades) a } \\
\text { una persona que presenta } \\
\text { lesiones causadas por } \\
\text { pénfigo vulgar }\end{array}$ & $\begin{array}{l}\text { Cortés LN, } \\
\text { Santiago SG }{ }^{(8)}\end{array}$ & $\begin{array}{l}2014 \\
\text { Nurses }\end{array}$ & Mexico & $\begin{array}{l}\text { Case study } \\
\text { Level } 5\end{array}$ \\
\hline 2 & LILACS & $\begin{array}{l}\text { Curativo de hidrofibra } \\
\text { com prata: opção } \\
\text { de tratamento para } \\
\text { pênfigo vulgar }\end{array}$ & $\begin{array}{l}\text { Andrade SMF; } \\
\text { Pontes MC; Sano } \\
\text { DT; Martins } \\
\text { ACGP; Gonzaga } \\
\text { Júnior JL }{ }^{(9)} \text {. }\end{array}$ & $\begin{array}{l}2012 \\
\text { Physicians } \\
\text { Nurse }\end{array}$ & Brazil & $\begin{array}{l}\text { Case study } \\
\text { Level } 5\end{array}$ \\
\hline 3 & LILACS & $\begin{array}{l}\text { Presentación de un caso } \\
\text { de pénfigo vulgar }\end{array}$ & $\begin{array}{l}\text { Zárate ZB, } \\
\text { Hernández JCM, } \\
\text { Naranjo AS(10). }\end{array}$ & $\begin{array}{l}2012 \\
\text { Physicians }\end{array}$ & Colombia & $\begin{array}{l}\text { Case study } \\
\text { Level } 5\end{array}$ \\
\hline 4 & $\begin{array}{l}\text { LILACS } \\
\text { BDENF } \\
\text { Scopus }\end{array}$ & $\begin{array}{l}\text { Evolução do cuidado de } \\
\text { enfermagem ao cliente } \\
\text { com pênfigo: revisão } \\
\text { integrativa de literatura }\end{array}$ & $\begin{array}{l}\text { Brandão ES; } \\
\text { Santos I dos; } \\
\text { Carvalho MR; } \\
\text { Pereira SK }\end{array}$ & $\begin{array}{l}2011 \\
\text { Nurses }\end{array}$ & Brazil & $\begin{array}{l}\text { Literature Review } \\
\text { Nível } 4\end{array}$ \\
\hline
\end{tabular}

Chart 1 - Profile of the publications selected in the theme. Niterói, RJ, 2018 Source: The authors (2018). 


\begin{tabular}{|c|c|c|c|c|c|c|}
\hline $\mathbf{N}$ & Database & Title & Author & $\begin{array}{c}\text { Year } \\
\text { Category }\end{array}$ & Country & $\begin{array}{c}\text { Type of study/ } \\
\text { Level of evidence }\end{array}$ \\
\hline 5 & $\begin{array}{l}\text { LILACS } \\
\text { BDENF } \\
\text { Scopus }\end{array}$ & $\begin{array}{l}\text { Evidências do cuidar } \\
\text { de pessoas com } \\
\text { pênfigo vulgar: desafio } \\
\text { à enfermagem }\end{array}$ & $\begin{array}{l}\text { Brandão ES; } \\
\text { Santos I dos }\end{array}$ & $\begin{array}{l}2013 \\
\text { Nurses }\end{array}$ & Brazil & $\begin{array}{l}\text { Literature Review } \\
\text { Nível } 4\end{array}$ \\
\hline 6 & Scopus & $\begin{array}{l}\text { Redução da dor em } \\
\text { clientes com dermatoses } \\
\text { imunobolhosas: avaliação } \\
\text { pela lógica fuzzy. }\end{array}$ & $\begin{array}{l}\text { Brandão ES; } \\
\text { Santos I dos; } \\
\text { Lanzillotti, RS }{ }^{(13)} \text {. }\end{array}$ & $\begin{array}{l}2016 \\
\text { Nurses }\end{array}$ & Brazil & $\begin{array}{l}\text { Quasi-experimental study } \\
\text { Level } 3\end{array}$ \\
\hline 7 & Scopus & $\begin{array}{l}\text { Radiation } \\
\text { induced pemphigus } \\
\text { vulgaris of the breast. }\end{array}$ & $\begin{array}{l}\text { Vigna-Taglianti } \\
\text { R; Russi } \\
\text { EG; Denaro } \\
\text { N; Numico } \\
\text { G, Brizio R }{ }^{(14)} \text {. }\end{array}$ & $\begin{array}{l}2011 \\
\text { Non- } \\
\text { specified }\end{array}$ & Italy & $\begin{array}{l}\text { Case study } \\
\text { Level } 5\end{array}$ \\
\hline 8 & Scopus & $\begin{array}{l}\text { Nursing diagnoses in } \\
\text { pemphigus vulgaris: a } \\
\text { case study }\end{array}$ & $\begin{array}{l}\text { Pena SB; } \\
\text { Guimarães HC; } \\
\text { Bassoli SR, Casarin } \\
\text { SN; Herdman TH; } \\
\text { de Barros AL }{ }^{(15)} \text {. }\end{array}$ & $\begin{array}{l}2013 \\
\text { Nurses }\end{array}$ & Brazil & $\begin{array}{l}\text { Case study } \\
\text { Level } 5\end{array}$ \\
\hline
\end{tabular}

Chart 1 - Cont.

\begin{tabular}{|c|c|c|}
\hline $\mathbf{N}$ & Primary bandages & Aspects that influence the evolution of the skin lesions \\
\hline 1 & $\begin{array}{l}\text { Antimicrobial gel } \\
\text { (silver gel) } \\
\text { Hydrogel } \\
\text { Hydrocolloid }\end{array}$ & $\begin{array}{l}\text { The gel mentioned is associated to prevent infection. } \\
\text { In case of infection in lesions, its use is recommended for } 14 \text { days. Later, the } \\
\text { hydrogel and the hydrocolloid are recommended every } 3 \text { days, with positive } \\
\text { results in the evolution of the lesions. } \\
\text { Pain control should be conducted with systemic analgesics before the wound } \\
\text { is bandaged. }\end{array}$ \\
\hline 2 & Silver-containing hydrofiber & $\begin{array}{l}\text { Two bandages were used and remained for five days each, totaling } 10 \text { days of } \\
\text { treatment with significant improvements in the lesions. } \\
\text { The need for systemic topical treatment association was highlighted. }\end{array}$ \\
\hline 3 & Corticoids & $\begin{array}{l}\text { Concludes that systemic and occasionally topical treatments enable } \\
\text { lesion scarring. }\end{array}$ \\
\hline 4 & $\begin{array}{l}\text { Antibiotics } \\
\text { Ointment-moisturized paper } \\
\text { Sterilized vaseline } \\
\text { Corticoid-based ointment }\end{array}$ & $\begin{array}{l}\text { Recommends the use of systemic antibiotics to treat infections in lesions } \\
\text { regardless of topical antibiotics use - risk of bacterial resistance (indiscriminate use). } \\
\text { Opposes the counter-recommendation of occlusive bandages due to the risk of } \\
\text { lesion adherence in the contact surface, in addition to the possibility of generating } \\
\text { infections, infestations, and to difficulties resting and changing positions that can } \\
\text { lead to pressure lesions. }\end{array}$ \\
\hline
\end{tabular}

Chart 2 - Synthesis of the articles selected. Niterói, RJ, 2018

Source: the authors (2018). 


\begin{tabular}{|c|c|c|}
\hline $\mathbf{N}$ & Primary bandages & Aspects that influence the evolution of the skin lesions \\
\hline 5 & $\begin{array}{l}\text { Corticoids } \\
\text { Antibiotics } \\
\text { Hydrophilic ointment }\end{array}$ & $\begin{array}{l}\text { Concludes that the content of the articles analyzed is superficial and has a low } \\
\text { level of evidence ( } 4-5) \\
\text { Highlights the need for clinical studies capable of establishing the real effects of } \\
\text { the bandages recommended. } \\
\text { Highlights the use of topical corticoids to control mild to moderate levels of } \\
\text { the disease. } \\
\text { The articles selected consider topical care as complementary to the } \\
\text { medication treatment. }\end{array}$ \\
\hline 6 & Gauze with vaseline & $\begin{array}{l}\text { Considered relevant in reducing the intensity of pain that happened after the } \\
\text { bandages mentioned were applied, which promotes the maintenance of a } \\
\text { humid environment, avoiding dryness in the site of lesions and preventing } \\
\text { against adherence. This bandaging promoted pain reduction, increased mobility } \\
\text { and improved sleeping patterns, offering more comfort to the client and more } \\
\text { willingness and energy for self-care and for confronting the disease. }\end{array}$ \\
\hline 7 & $\begin{array}{l}\text { Vitamin-E ointments } \\
\text { Hydrofiber } \\
\text { Hydrocolloid }\end{array}$ & $\begin{array}{l}\text { Describes the features of carboxymethyl cellulose bandages (hydrocolloid and } \\
\text { hydrofiber): it adsorbs exudates and transforms into a gel that reduces friction and } \\
\text { pain during movements. } \\
\text { Concludes that appropriate hydrocolloid and hydrofiber use optimized healing } \\
\text { and improved the comfort of the patient, reducing friction, trauma, pain, } \\
\text { and pruritus. } \\
\text { Associated to steroids, vitamin-E ointments and hydrofiber (in the more exudative } \\
\text { stage) and hydrocolloid (in the less exudative stage), it resulted in reports of } \\
\text { less discomfort. }\end{array}$ \\
\hline 8 & $\begin{array}{l}\text { Plastic sheet soaked with } \\
\text { unsaturated fatty acid }\end{array}$ & $\begin{array}{l}\text { Describes features of unsaturated fatty acids: good absorption by the body; potent } \\
\text { antioxidant action; protects the skin DNA; inhibits free-radicals that prevent tissue } \\
\text { reparation processes. } \\
\text { After } 21 \text { days of systemic treatment and associated topical treatment, most } \\
\text { lesions in the surface of the body were granulated. There were also significant } \\
\text { epithelialization and diminution in the edema around the wound. }\end{array}$ \\
\hline
\end{tabular}

Chart 2 - Cont.

\section{DISCUSSION}

As Chart 2 shows, it is pertinent to highlight an observation made by three of the articles analyzed ${ }^{(11-13)}$, which could be extended to the others: the recommendation of occlusive bandages for the lesions of people with PV. In this context, the study stated that the absence of bandaging exposes the persons to the risk of lesion adherence to surfaces, in addition to the possibility of generating infections, infestations, and to difficulties resting and changing positions, which can lead to pressure lesions.
A considerable number of medications was found to be recommended as primary bandaging, such as corticoids and topical antibiotics, as shown in Chart 2. On the other hand, some articles addressed the use of technologies that can be prescribed by nurses, such as: hydrogel, hydrocolloid, hydrofiber (containing or not silver), sterile vaseline, and unsaturated fatty acids.

Two case studies ${ }^{(8-9)}$ presented in Chart 2 recommended bandages with silver to prevent and/or treat infections related to damages to skin integrity, which are generally characterized by extensive and disseminated lesions ${ }^{(2)}$. The 
risk of infections is associated to the hospital environment and to the low immunity resulting from the high dosage of systemic corticoids and immunosuppressive drugs, due to advanced age and/or chronic diseases such as diabetes $s^{(2,16)}$. Concerning this issue, a study stood out that was carried out to identify the nursing diagnoses of patients with immunobullous dermatoses, among which pemphigus vulgaris. Among the nursing diagnoses, "risk of infection", defined as the risk of being invaded by pathogenic organisms, was found in all participants of said study ${ }^{(16)}$.

One of the articles ${ }^{(9)}$ cited the commercial name of the silver bandages used during the case study, which allows one to infer that there is a conflict of interests.

Regarding the use of topical antibiotics, cited in two other articles ${ }^{(11-12)}$, it stands out that, in addition to not having scientifically proved efficiency for the treatment of lesions, its indiscriminate use increases the risk of allergies, increases tenderness and bacterial resistance. Currently, for the topical treatment of colonized or infected wounds, bandages containing silver as their antimicrobial agent are recommended. However, it should be highlighted that, in case of infection, systemic antibiotic therapy is considered to be indispensable ${ }^{(1)}$.

The indication of the hydrocolloid in two articles ${ }^{(8,14)}$ led to questions about how the product was presented in the studies. This information was not present and the product may come in sheets, cream, grains, and fiber. Since adhesive bandages are counterindicated in PV lesions due to the risk of skin detachment during the removal of the bandage, it can be inferred that autoadhesive hydrocolloids are inadequate. Additionally, the bandage in question is not absorptive, being indicated to lesions with low to moderate exudate drainage ${ }^{(3)}$, which is not the profile of PV lesions. Therefore, considering the features and the exudative nature of PV lesions ${ }^{(1)}$, it is possible to question the indication of hydrocolloid and hyrdrogel as primary bandages ${ }^{(8)}$, since these products do not absorb the exudate and doing so is relevant for the healing of the wound ${ }^{(3)}$ in PV cases.

In turn, two articles ${ }^{(9,14)}$ highlighted exudate control with the use of a hydrofiber bandage, emphasizing that it increases the wellbeing/comfort of the person affected by PV. One of these articles ${ }^{(9)}$ mentioned an increase in the interval between bandage exchange, that is, every five days, as the responsible for the reduction of the discomfort mentioned, since the exchanges exposes the patient to pain. On the other hand, the person affected by this disease, who uses this bandage, stays five days without body hygiene, which can cause great discomfort. Another study ${ }^{(14)}$ attributed this benefit to the gelation capacity of this bandage, since this characteristic diminishes friction, trauma, pain, and pruritus in the site of the lesion. However, considering the level of evidence of these studies ${ }^{(6)}$ and the high cost of these bandages, clinical trials are necessary to investigate the real benefits, in addition to carrying out a cost-efficiency analysis of these bandages.

On the other hand, an article ${ }^{(13)}$ with level 3 evidence, that is, the most significant of the studies mentioned, presented positive results with regards to promoting the comfort of people with PV. The bandage proposed, sterilized gauze with vaseline, which should be prepared according to a protocol, led to diminution in pain and smell, in addition to increasing mobility. According to the authors of the article, this bandage must be exchanged every 24 hours, allowing for daily hygiene. This bandage maintains the humidity required in the site of the lesion, avoiding adhesion of the dressing and resulting in diminished pain. Consequently, it improves mobility and the sleeping patterns of the person with the diagnostic. The exudate is absorbed by the secondary bandage, and sterile compresses are fixed with bandages or tubular mesh. The daily exchange of the bandage and the cleansing of the lesions with $36^{\circ} \mathrm{C}$ saline reduces the foul smell, also improving the wellbeing of the individuals. As mentioned, the preparation of the gauze with vaseline must follow a protocol that guides the amount of gauze and vaseline to be used.

It should be mentioned that another study ${ }^{(11)}$ also cited vaseline as a primary product, but does not offer sufficient scientific data to prove its efficacy in the context studied.

Regarding unsaturated or essential fatty acids (EFAs), cited in only one of the articles ${ }^{(15)}$, the microscopic effects of this product was detailed, to the detriment of its macroscopic ones, such as granulation, epithelialization, and diminution of edemas. However, it stands out that the benefits of this material in the treatment of lesions are not scientifically proven ${ }^{(17)}$.

Although there are positive aspects to the evolution of the lesions, none of the case studies selected $\mathrm{d}^{(8-10,14,15)}$ could prove the efficiency of the bandages indicated because their treatments were carried out with a single patient, meaning these researches have low scientific evidence levels. Regarding the other bandages cited (corticoids, hydrophilic ointments, and vitamin-E ointments), it was found that the studies do not explore their effects on the scarring process ${ }^{(10-12)}$.

\section{- CONCLUSION}

Considering the articles selected, the sterilized gauze with vaseline stands out as the most adequate primary bandage for wound dressing PV patients, taking into account the level of evidence of the study carried out and the promotion of comfort from the bandage, diminishing pain, body exposure, and increasing mobility and improving sleeping patterns. 
The other bandages mentioned, such as silver-containing hydrofiber, hydrocolloid, and vitamin-E, were presented in case studies with a single patient, which shows how urgent it is to carry in-depth studies on the theme, including studies on the cost of the bandages as related to their efficiency. The need for daily exchanges should also be a requirement, considering the need for body hygiene to promote comfort.

Considering the scarcity of high evidence level studies, which was the main limitation of this study, it is essential to alert nurses about the need for carrying out clinical studies on the bandages to be used to attend these clients, as to promote their comfort and prevent harm, in addition to reducing costs.

\section{QREFERENCES}

1. Hanauer L, Abulafia LA, Azulay DR, Azulay RD. Buloses. Azulay - Dermatologia. 7ed. Rio de Janeiro: Guanabara Koogan, 2017. p. 267-82.

2. Brandão ES, Santos I, Costa MTF, Jesus PBR. Pênfigos. In: Gamba MA, Petri V, Costa MTF. Feridas: prevenção, causas e tratamento. Rio de Janeiro: Santos; 2016. p. 223-7.

3. Aron S, Bergo AMA, Marcondes MGSG. Curativos e coberturas. In: Gamba MA, Petri V, Costa MTF. Feridas: prevenção, causas e tratamento. Rio de Janeiro: Santos; 2016. p. 283-6.

4. Botelho LL, Cunha CCA, Macedo M. 0 método da revisão integrativa nos estudos organizacionais. Gestão Soc (Online). 2011;5(11):121-36. doi: https://doi. org/10.21171/ges.v5i11

5. Grupo Anima Educação. Manual Revisão Bibliográfica Sistemática Integrativa: a pesquisa baseada em evidências. Belo Horizonte: Grupo Anima Educação; 2014.

6. Souza MT, Silva MD, Carvalho R. Revisão integrativa: 0 que é e como fazer. Einstein. 2010;8(1):102-6.

7. Galvão CM, Sawada NO, Mendes IAC. A busca das melhores evidências. Rev Esc Enferm USP. 2003;37(4):43-50. doi: https://doi.org/10.1590/5008062342003000400005
8. Cortés LN, Santiago SG. Aplicación de un plan de cuidados enfermeros utilizando el modelo de Virginia Henderson (catorce necesidades) a una persona que presenta lesiones causadas por pénfigo vulgear. Rev Enferm Neurol [on line] 2014 [cited 2018 Apr 10];13(1):37-42. Available from: http://www. medigraphic.com/cgi-bin/new/resumen.cgi?IDARTICULO=48956

9. Andrade SMF, Pontes MC, Sano DT, Martins ACGP, Gonzaga Júnior UL. Curativo de hidrofibra com prata: opção de tratamento para pênfigo vulgar. Surg Cosmet Dermatol. 2012;(3):274-6.

10. Zárate ZB, Hernández ICM, Naranjo AS. Presentación de un caso de Pénfigo Vulgar. Rev Univ Ind Santander, Salud. 2012;44(3):49-55.

11. Brandão ES, Santos I, Carvalho MR, Pereira SK. Evolução do cuidado de enfermagem ao cliente com pênfigo: revisão integrativa de literatura. Rev Rnferm UERJ. 2011;19(3):479-84.

12. Brandão ES, Santos I. Evidências do cuidar de pessoas com pênfigo vulgar: desafio à enfermagem. Online Braz J Nurs. 2013 [cited 2018 Mar 15];12(1):162-77. Available from: http://www.objnursing.uff.br/index.php/nursing/article/view/3674

13. Brandão ES, Santos I, Lanzillotti RS. Redução da dor em clientes com dermatoses imunobolhosas: avaliação pela lógica fuzzi. Online Braz J Nurs. 2016 [cited 2018 May 10];15(4):675-82. Available from: http://www.objnursing.uff.br/index. php/nursing/article/viewFile/5467/pdf_2n

14. Vigna-Taglianti R, Russi EG, Denaro N, Numico G, Brizio R. Radiation-induced pemphigus vulgaris of the breast. Cancer Radiother. 2011;15(4):334-7. doi: https://doi.org/10.1016/j.canrad.2011.01.006

15. Pena SB, Guimarães HC, Bassoli SR, Casarin SN, Herdman TH, Barros AL. Nursing diagnoses in Pemphigus Vulgaris: a case study. Int I Nurs Knowl. 2013;24(3):176-9. doi: https://doi.org/10.1111/j.2047-3095.2013.01250

16. Brandão ES, Santos I, Lanzillotti RS, Ferreira AM, Gamba MA, Azulay-Abulafia L. Nursing diagnoses in patients with imune-bullous dermatoses. Rev Latino-Am Enfermagem. 2016 [cited 2018 Mar 10];24:e2766. Available from: http://www. scielo.br/scielo.php?script=sci_isoref\&pid=S0104-11692016000100385\&ln $g=e n \& t \operatorname{lng}=e n$

17. Ferreira AM, Souza BMV, Rigotti MA, Loureiro MRD. Utilização dos ácidos graxos no tratamento de feridas: uma revisão integrativa da literatura nacional. Rev Esc Enferm USP. 2012 [cited 2017 Nov 04];46(3)752-60. Available from: http://www.scielo.br/scielo.php?script=sci_arttext\&pid=S00 80-62342012000300030

\section{- Corresponding author:}

Euzeli da Silva Brandão

E-mail: euzelibrandão@gmail.com

\section{Associate editor:}

Dagmar Elaine Kaiser

Received: 08.13.2019

Editor-in-chief:

Approved: 12.04.2019

Maria da Graça Oliveira Crossetti 